\title{
The Screening for the Antitrypanosomal Potentials of the Extracts of Curcuma longa $\mathrm{L}$.
}

\section{Muhammad Muhsin Fathuddin ${ }^{1,2 *}$ and Rafeedah Fathuddin ${ }^{1}$ \\ ${ }^{1}$ Department of Microbiology, Ahmadu Bello University, Zaria, Kaduna State, Nigeria \\ ${ }^{2}$ Department of Microbiology, Kaduna State University, Kaduna, Kaduna State, Nigeria \\ *Corresponding Author: Muhammad Muhsin Fathuddin, Department of \\ Microbiology, Kaduna State University, Kaduna, Kaduna State, Nigeria.}

DOI: 10.31080/ASMI.2020.04.0771
Received: November 23, 2020

Published: January 28, 2021

(C) All rights are reserved by Muhammad

Muhsin Fathuddin and Rafeedah

Fathuddin.

\begin{abstract}
Background: Extracts of Curcuma longa rhizome extracts were investigated for their biological activity.

Methodology: The presence of phytochemicals and antitrypanosomal activities were investigated.

Results: The extracts contained the phytochemicals (Alkaloid, Anthraquinone, Carbohydrates, Cardiac Glycosides, Flavonoid, Glycosides, Phenols, Saponin, Steroid, Tannin and Triterpenes) in table 1 and 2 . The extracts showed very good activity against the parasite from figure 1, 2 and 3.

Discussion: The presence of the phytochemical confirms their medicinal potentials. The crude extracts of Curcuma longa were analyzed in vitro for trypanocide activity on Trypanosoma brucei brucei at concentration $100.0 \mathrm{mg} / \mathrm{ml}, 50.0 \mathrm{mg} / \mathrm{ml}, 25 \mathrm{mg} / \mathrm{ml}, 12.5 \mathrm{mg} /$ $\mathrm{ml}$ and $6.25 \mathrm{mg} / \mathrm{ml}$. The best activity was seen in Petroleum ether extract, followed by the ethanol extract, then Chloroform which was still impressive.

Conclusion: The results obtained from this study show that the turmeric contains potential antimicrobial components which will be of great use for the advancement of remedies by pharmaceutical industries as a therapy against various diseases.

Keywords: Curcuma longa; Petroleum Ether; Chloroform; Ethanol; Antitrypanosomal Activity; Trypanosoma brucei brucei
\end{abstract}

\section{Abbreviations}

A.B.U.: Ahmadu Bello University; AAT: Animal African Trypanosomiasis; ABUCAUC: Ahmadu Bello University Ethics Committee on Animal Use and Care; AT: African Trypanosomiasis; C. longa: Curcuma longa; CPCSEA: Committee for the Purpose of Control and Supervision on Experiments on Animals; HAT: Human African Trypanosomiasis; NARICT: National Research Institute for Chemical Technology; RBC: Red Blood Cells; T. b. brucei: Trypanosoma brucei brucei.

\section{Introduction}

African trypanosomiasis (AT) are extracellular protozoan parasites that cause chronic infections in Humans, and their livestock, and are predominantly transmitted by Glossina sp. Trypanosoma congolense and Trypanosoma brucei brucei (T. b. brucei), are among the most common trypanosomes, which causes livestock infections [1]. Human African Trypanosomiasis (HAT) and Animal African Trypanosomiasis (AAT) form the two main forms of AT. And it is projected about 70 million population in around 36 countries of sub-Saharan Africa may be at the menace of HAT while AAT looms over the lives of millions of cattle every year. HAT is caused by two strains of $T$. $b$. that infect either humans (T. b. gambiense) or animals (T. b. rhodesiense), while AAT portends the lives of several million herds of cattle every year, thereby necessitating new approaches of contending the disease [2]. Primary diagnosis of the presence of T. $b$. at the first stage of infection can partake a significant impact on a patient's outcome by permitting timely and adequate treatment before the disease progresses into a second stage. This is significant because, at this later phase, the parasite infiltrates the central nervous system, which leads towards the neuropsychiatric 
The Screening for the Antitrypanosomal Potentials of the Extracts of Curcuma longa L.

manifestations. such as deep sensory disturbances, derangement or sleep disorders, that sternly compromise the quality of life of the patient. This second stage is fatal if untreated and treatments used to treat it are expensive and/or highly toxic. In contrast, drug therapy for early-stage HAT is effective and only mildly toxic [3].

The name 'turmeric' has originated from the Feudal Latin name terramerita, which became terre merite of French, meaning deserved earth or meritorious earth, a reputation by which powdered turmeric was known in commerce [4]. Turmeric (Curcuma longa L., family: Zingiberaceae) is one amongst the foremost important and ancient spices of India and a conventional item of export. It's used as condiment, dye, drug and cosmetics additionally to its use in religious ceremonies. The rhizome is that the economic part of turmeric and is well-known for its medicinal properties together with its application in cosmetics and as a natural dye within the textile industry [5]. Altogether South Asian countries, turmeric has been in use from ancient time as a spice, food preservative, colouring agent, and cosmetic and within the traditional systems of drugs (Ayurveda, Sidha, Tibetan and Unani) [4].

Turmeric is one amongst the species which has been used an extended time as a medicinal plant for antibacterial activity because it contains active curcumin. However, curcumin isn't enough to create this compound widely utilized in the clinical field because of its low bioavailability [6]. Turmeric is thought to be the "golden spice" also as of the "spice of life." It's stood employed in India as a medicinal plant and held sacred from historical time. Turmeric has a sturdy relationship with the socio-cultural life of the individuals of the Indian subcontinent. This "earthy herb of the Sun" with the orange-yellow rhizome was well-thought-out as the "herb of the Sun" by the people of the Vedic period. No wonder the historians regarded turmeric as the Oushadhi: "the healing herb', 'the most outstanding herb', 'the one herb above all others', etc. Turmeric has a minimum of 6000 years of documented history of its practice as medicine and in many socio-religious usages [4]. Recent researches on turmeric are focused on its Antibacterial [7-9], Anticarcinogenic [10-12] Antidiabetic [13-15], Anti-Inflammatory [16-18], Antimicrobial [19-21], Antioxidant [22-24], Antirheumatic [25,26], Antiviral [27-29], Choleretic [30,31].

\section{Materials and Methods}

Preparation of medicinal plants

- Collection of Plant Materials: The fresh rhizome part of Curcuma longa was collected from Area BZ, A.B.U., Zaria and authenticated at Herbarium Section, Department of Biological Sciences, A.B.U., Zaria.

- Preparation of the rhizome extracts: The rhizome was washed with distilled water, air-dried at room temperature for three days and then, pulverized using a clean electronic grinder. The $100.0 \mathrm{~g}$ portion of pulverised rhizome was put into 250 $\mathrm{ml}$ of petroleum ether for 24 hours. Then the solvent was filtered and the residue was air-dry and repackage. This was repeated for chloroform and ethanol respectively. Each extract was filtered, the excess solvent was recovered using a recovery apparatus. The remaining extract was evaporated to dryness at room temperature in a steady air current over a water bath as described by Abubakar., et al. (2020) [32].

- Phytochemical Studies: The phytochemical analysis was carried out quantitatively to determine the presence of Alkaloid, Phenols, Flavonoids, Saponins, Tannins, Resin, Glycosides and Steroids using the methods described by Abubakar., et al. (2020) [32].

- Preparation of the test samples: In the study of the antitrypanosomal activities of this plant, concentrations of 100.00$6.25(\mathrm{mg} / \mathrm{ml})$ of each extract were used for the screening. This was done by dissolving $10.00 \mathrm{~g}(1000 \mathrm{mg})$ of the extracts in $10 \mathrm{ml}$ DSMO solvent i.e., $100.00 \mathrm{mg} / \mathrm{ml}$. And subsequent were made via serial dilutions $50.00-6.25 \mathrm{mg} / \mathrm{ml}$ using dextrose saline and were freshly prepared as accordance by Fathuddin and Inabo, (2017) [33].

- Sources and Maintenance of The Test Organisms: The parasite, $T$. $b$. brucei was obtained from the NARICT, Basawa, Zaria, Nigeria. The organisms were maintained in the laboratory by the continuous passage in rats with accordance to Fathuddin and Inabo (2017) [33].

- Laboratory Animals: Wister strain albino rats were obtained and kept at the animal house of NARICT. The animals have maintained following Fathuddin and Inabo (2017) [33]. The experimental animal was handled per the guidelines of the World Health Organization. (2010) [34]; Committee for the Purpose of Control and Supervision on Experiments on Animals (CPCSEA) Guidelines for Laboratory Animal Facility (2010) [35]; A.B.U. Ethics Committee on Animal Use and Care [ABUCAUC] (2010) [36]. All protocols and procedures used in this study were reviewed and approved by the ABUCAUC Policy. The ABUCAUC approval number is ABUCAUC/2012/ MICROB/APP/001. 


\section{Antitrypansomal bioassay}

The trypanosome parasitaemia was determined by the use of wet mount according to The Wet and Thick Blood Film Method, and microscopic evaluation at 400x magnification using The Rapid Matching Method Assessment of the in vitro trypanocidal activity was conducted according to Fathuddin and Inabo, (2017) [33]. The Positive Control was performed using recommended concentrations of Diminazine aceturate (Sequene, PI Drugs and Pharmaceuticals LTD India) and the negative control was just mixed in dextrose saline. The 96 round-bottom well microtiter plate was incubated at room temperature [33].

\section{Results and Discussion}

- Collection of Plant Materials: The fresh rhizome part of Curcuma longa was collected from Area BZ, Ahmadu Bello University Campus, Samaru, Zaria and authentication were issued by Herbarium Section, Department of Biological Sciences, Ahmadu Bello University, Zaria; given as Voucher No.: 1152

- Phytochemical analysis: The extracts obtained had an appearance of Petroleum Ether - Yellow Oily Liquid; Chloroform - Dark Orange Residue; and, Ethanol -Orange Sticky Residue which is presented in table 1 . The phytochemical constituents of Petroleum Ether, Chloroform and Ethanol Extract of rhizome Curcuma longa is presented in table 2. The result showed that the extracts contain the following Phytochemicals: Alkaloid, Anthraquinone, Carbohydrates, Cardiac Glycosides, Flavonoid, Glycosides, Phenols, Saponin, Steroid, Tannin and Triterpenes. The finding was similar to what various authors noted [7,10,37-39].

- Antitrypansomal Bioassay: The in vitro analysis result for the extracts shown in figure 1, 2 and 3. The Petroleum ether, chloroform and ethanol extracts had activity on T. b. brucei. From figure 1, it can be seen that the Petroleum ether extract, at $100.00-25.00 \mathrm{mg} / \mathrm{ml}$ cleared all the parasite in the blood. However, the concentration was too strong that it ended up even lyse the RBC. The concentration of 12.50 cleared the parasite within 10 minutes while the $6.25 \mathrm{mg} / \mathrm{ml}$ cleared within 20 minutes. The Chloroform extract had activity between 100.00 and $50.00 \mathrm{mg} / \mathrm{ml}$ but it took $25.00 \mathrm{mg} / \mathrm{ml}-15 \mathrm{~min}$ utes, $12.50 \mathrm{mg} / \mathrm{ml}$ - 35 minutes and $6.25 \mathrm{mg} / \mathrm{ml}-55$ minutes to clear the parasite. The Ethanolic extract like the chloroform extract cleared the parasite but 100.00 and $50.00 \mathrm{mg} / \mathrm{ml}$ but it took $25.00 \mathrm{mg} / \mathrm{ml}-10$ minutes, $12.50 \mathrm{mg} / \mathrm{ml}-20$ minutes and $6.25 \mathrm{mg} / \mathrm{ml}-30$ minutes, which was faster the chloroform extract but slower than petroleum ether. The morphology of the RBC was maintained at lower concentrations i.e., 25.00 $6.25 \mathrm{mg} / \mathrm{ml}$. The positive control was most effective in clearing all the parasite in less than 5 minutes, while the negative control lasted about 80 minutes. The result of the present study showed that $C$. longa has activity against $T$. b. brucei. authors findings, like Le, et (2019) [40] found that the interesting effect of the C. longa EO against $T$. $b$. brucei bloodstream form with a good selectivity while using essential oil of $C$. longa. Most research works focus primarily on the active ingredient: curcumin. Haddad., et al. (2011) [41] stated that some curcumin derivatives have potent trypanocidal activity against the $T$. $b$. brucei bloodstream form. Even, Jonah and Enoh (2020) [42] found that curcumin from rhizomes of $C$. longa contains active principles with significant in vitro antitrypanosomal activity against T. b. brucei.

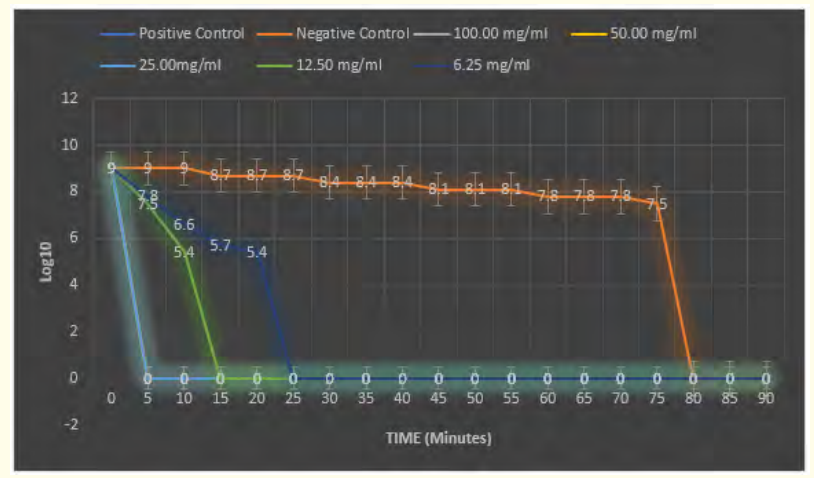

Figure 1: Petroleum ether extract of $C$. longa against T. b. brucei.

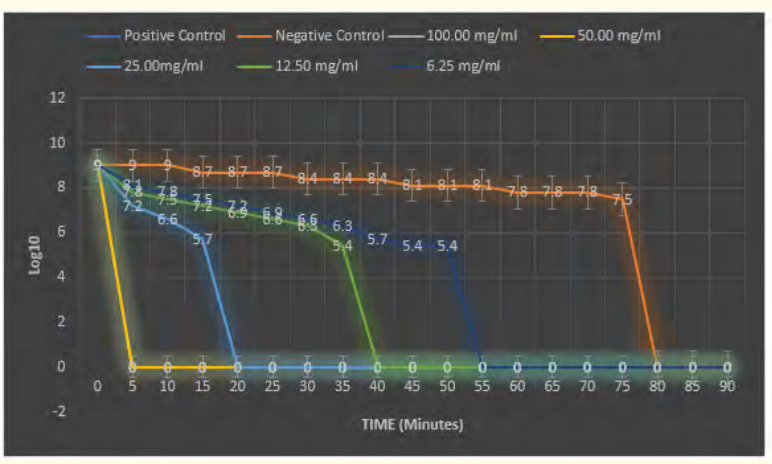

Figure 2: Chloroform extract of $C$. longa against T. b. brucei.

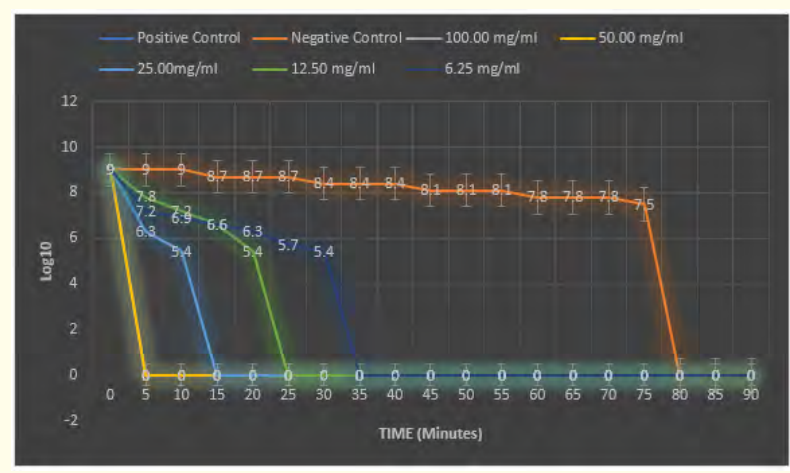

Figure 3: Ethanol extract of C. longa against T. b. brucei. 
The Screening for the Antitrypanosomal Potentials of the Extracts of Curcuma longa L.

\begin{tabular}{|l|c|c|}
\hline $\begin{array}{l}\text { Solvent } \\
\text { Used }\end{array}$ & $\begin{array}{c}\text { Colour and } \\
\text { consistency }\end{array}$ & $\begin{array}{c}\text { Percentage Yield (\%W/W) on } \\
\text { Fresh Weight Basis }\end{array}$ \\
\hline $\begin{array}{l}\text { Petroleum } \\
\text { Ether }\end{array}$ & $\begin{array}{c}\text { Yellow Oily } \\
\text { Liquid }\end{array}$ & 0.16 \\
\hline $\begin{array}{l}\text { Chloro- } \\
\text { form }\end{array}$ & $\begin{array}{c}\text { Dark Orange } \\
\text { Residue }\end{array}$ & 0.88 \\
\hline Ethanol & $\begin{array}{c}\text { Orange Sticky } \\
\text { Residue }\end{array}$ & 0.96 \\
\hline
\end{tabular}

Table 1: The constitute of the various extracts of $C$. longa (rhizome).

\begin{tabular}{|c|c|c|c|c|c|}
\hline $\begin{array}{l}\text { S/ } \\
\text { No. }\end{array}$ & $\begin{array}{c}\text { Secondary } \\
\text { Metabo- } \\
\text { lites }\end{array}$ & Name of Test & $\begin{array}{l}\text { Petro- } \\
\text { leum } \\
\text { ether }\end{array}$ & $\begin{array}{l}\text { Chlo- } \\
\text { roform }\end{array}$ & $\begin{array}{c}\text { Etha- } \\
\text { nol }\end{array}$ \\
\hline 01 & $\begin{array}{l}\text { Carbohy- } \\
\text { drates }\end{array}$ & $\begin{array}{l}\text { Molisch's } \\
\text { Test }\end{array}$ & + & + & + \\
\hline 02 & Glycosides & Fehling's Test & + & + & + \\
\hline 03 & Phenols & $\begin{array}{l}\text { Ferric chlo- } \\
\text { ride Test }\end{array}$ & + & + & + \\
\hline \multirow[b]{2}{*}{04} & \multirow{2}{*}{$\begin{array}{c}\text { Antra- } \\
\text { quinones } \\
\text { Derivatives }\end{array}$} & $\begin{array}{c}\text { Borntrager's } \\
\text { Test }\end{array}$ & - & + & + \\
\hline & & $\begin{array}{c}\text { Modified } \\
\text { Borntrager's } \\
\text { Test }\end{array}$ & + & + & + \\
\hline \multirow[t]{2}{*}{05} & \multirow{2}{*}{$\begin{array}{c}\text { Cardiac } \\
\text { Glycosides }\end{array}$} & $\begin{array}{c}\text { Kella-Killiani } \\
\text { Test }\end{array}$ & + & + & + \\
\hline & & Kadde Test & + & + & + \\
\hline 06 & Steroid & $\begin{array}{c}\text { Salkowsk } \\
\text { Test }\end{array}$ & + & + & + \\
\hline 07 & Saponins & Frothing Test & + & + & + \\
\hline 08 & $\begin{array}{c}\text { Steroid }(\mathrm{S}) \\
\text { or Triter- } \\
\text { penes }(\mathrm{T})\end{array}$ & $\begin{array}{c}\text { Leibermen- } \\
\text { Burchards } \\
\text { Test }\end{array}$ & + & + & + \\
\hline \multirow[b]{2}{*}{09} & \multirow[b]{2}{*}{ Flavonoids } & Shinoda Test & + & + & + \\
\hline & & $\begin{array}{l}\text { Sodium hy- } \\
\text { droxide Test }\end{array}$ & + & + & + \\
\hline 10 & Tannins & $\begin{array}{c}\text { Ferric chlo- } \\
\text { ride Test }\end{array}$ & + & + & + \\
\hline \multirow{4}{*}{11} & \multirow{4}{*}{ Alkaloids } & $\begin{array}{c}\text { Dragendoff's } \\
\text { Test }\end{array}$ & + & + & + \\
\hline & & $\begin{array}{l}\text { Wagner's } \\
\text { Test }\end{array}$ & + & + & + \\
\hline & & $\begin{array}{c}\text { Picric acid } \\
\text { Test }\end{array}$ & + & + & + \\
\hline & & $\begin{array}{c}\text { Tannic acid } \\
\text { Test }\end{array}$ & + & + & + \\
\hline
\end{tabular}

Table 2: Phytochemical analysis of various extracts of $C$. longa (rhizome).

\section{Conclusions}

The preliminary phytochemical tests revealed the presence of carbohydrates, flavonoids, glycosides, phenolic compounds, reducing sugars, saponins, terpenoids, steroids and tannins within the rhizomes of $C$. longa L. The results obtained from this study show that the turmeric contains potential antimicrobial components which will be of great use for the advancement of remedies by pharmaceutical industries as a therapy against various diseases. The turmeric extract possesses significant activity against $T$. $b$. brucei. Consequently, it's fairly clear that turmeric being available in pure form, it might be easier to develop new drugs with fewer side effects and more efficiency. Because of being nontoxic with a wide spectrum of biological functions, turmeric may find its application within the formation of several medicinal products which can help in the treatment of various diseases in coming future [43]. In recent years, it has been seen that there is a continuous enthusiasm in treating various diseases with natural products. Further research is needed to supplementary investigate the efficacy of curcumin as a stand-alone drug or as a supplement of current drugs of choice because it has no antagonistic activities but might overcome their drawbacks [44].

\section{Acknowledgements}

The authors' wish to thank the staffs of the Department of Pharmacognosy, A.B.U. for their assistance during the Cold Extraction and Phytochemical Analysis. Similarly, wish to show gratitude toward the Staffs at the NARICT for their profundity and constructive discussions. Also, to Dr Habila Nathan (formerly with NARICT), presently at Department of Biochemistry and Molecular Biology, Monash University, Australia.

\section{Contributions and Conflict of Interests}

The authors contributed equally and declare no potential conflict of interests.

\section{Bibliography}

1. Ndungu K., et al. "Route of inoculation influences Trypanosoma congolense and Trypanosoma brucei brucei virulence in Swiss white mice". PLoS ONE 14.6 (2019): e0218441.

2. Dofuor A K., et al. "Antitrypanosomal Effects of Zanthoxylum zanthoxyloides (Lam.) Zepern. \& Timler Extracts on African Trypanosomes". Evidence-Based Complementary and Alternative Medicine (2019). 
The Screening for the Antitrypanosomal Potentials of the Extracts of Curcuma longa L.

3. Keck D., et al. "Highly Localized Enrichment of Trypanosoma brucei Parasites Using Dielectrophoresis". Micromachines 11.6 (2020): 625 .

4. Ravindran PN., et al. "Turmeric: The Genus Curcuma". CRC press (2007).

5. Abirami K., et al. "Phytochemical Profile and Antimicrobial Activity of Turmeric Grown in Andaman Islands". Journal of Pharmacognosy and Phytochemistry 8.6 (2019): 09-13.

6. Musyarrofah L., et al. "Acetylation of Curcumin from Turmeric Rhizome (Curcuma longa) with Ni/SiO2 and Pyridine Catalysts and Its Antibacterial Activity". In AIP Conference Proceedings 2242.1 (2020): 040037.

7. Patil V V., et al. "Phytochemical Analysis and Antibacterial Evaluation of Curcuma Longa and Curcuma Aromatica against Enteric Poultry Pathogens". International Journal of Pharmaceutical Sciences and Research 10.4 (2019): 2000-2003.

8. Varghese B., et al. "Biochemical synthesis of copper nanoparticles using Zingiber officinalis and Curcuma longa: Characterization and antibacterial activity study". Materials Today: Proceedings (2020).

9. Widiyanti P., et al. "Hyaluronic Acid-Chitosan/AgNPs Hydrogel Green Synthesis from Curcuma Longa as Antibacterial Anti Intraperitoneal Adhesion". Journal of International Dental and Medical Research 13.3 (2020).

10. Sharma M., et al. "Unveiling antimicrobial and anticancerous behavior of AuNPs and AgNPs moderated by rhizome extracts of Curcuma longa from diverse altitudes of Himalaya". Scientific Reports 10.1 (2020): 1-11.

11. Wei M M., et al. "A combination index and glycoproteomicsbased approach revealed synergistic anticancer effects of curcuminoids of turmeric against prostate cancer PC3 cells". Journal of Ethnopharmacology (2020): 113467.

12. Sabir S M., et al. "Phytochemical analysis and biological activities of ethanolic extract of Curcuma longa rhizome". Brazilian Journal of Biology (AHEAD) (2020).

13. Gaonkar V P and Hullatti K. "Indian Traditional medicinal plants as a source of potent Anti-diabetic agents: A Review". Journal of Diabetes and Metabolic Disorders (2020): 1-14.

14. Razzaq P A., et al. "A comprehensive review on antidiabetic properties of turmeric". Life Science Journal 17.10 (2020).

15. Den Hartogh D J., et al. "Antidiabetic properties of curcumin II: evidence from in vivo studies". Nutrients 12.1 (2020): 58.
16. Lee S Y., et al. "Anti-inflammatory Effect of Curcuma longa and Allium hookeri Co-treatment via NF-kB and COX-2 Pathways". Scientific Reports 10.1 (2020): 1-11.

17. Kim H., et al. "Puffing of Turmeric (Curcuma longa L.) Enhances its Anti-Inflammatory Effects by Upregulating Macrophage Oxidative Phosphorylation". Antioxidants 9.10 (2020): 931.

18. Lima E P., et al. "Anti-inflammatory and Antioxidant Activity of Nanoencapsulated Curcuminoids Extracted from Curcuma longa L. in a Model of Cutaneous Inflammation". Inflammation (2020): 1-13.

19. Teles A M., et al. "Cinnamomum zeylanicum, Origanum vulgare, and Curcuma longa essential oils: chemical composition, antimicrobial and antileishmanial activity". Evidence-Based Complementary and Alternative Medicine (2019).

20. Maghimaa M and Alharbi S A. "Green synthesis of silver nanoparticles from Curcuma longa $L$. and coating on the cotton fabrics for antimicrobial applications and wound healing activity". Journal of Photochemistry and Photobiology B: Biology 204 (2020): 111806.

21. Jayarambabu N., et al. "Green synthesis of $\mathrm{Cu}$ nanoparticles using Curcuma longa extract and their application in antimicrobial activity". Materials Letters 259 (2020): 126813.

22. Tanvir E M., et al. "Antioxidant properties of popular turmeric (Curcuma longa) varieties from Bangladesh". Journal of Food Quality (2017).

23. Yang Q Q., et al. "Phenolic profiles, antioxidant, and antiproliferative activities of turmeric (Curcuma longa)". Industrial Crops and Products 152 (2020): 112561.

24. Ibrahim J., et al. "Antioxidant and hepatoprotective potentials of curcuminoid isolates from turmeric (Curcuma longa) rhizome on CCl4-induced hepatic damage in Wistar rats". Journal of Taibah University for Science 14.1 (2020): 908-915.

25. Panaro M A., et al. "The Emerging Role of Curcumin in the Modulation of TLR-4 Signaling Pathway: Focus on Neuroprotective and Anti-Rheumatic Properties". International Journal of Molecular Sciences 21.7 (2020): 2299.

26. Zarei L., et al. "Systematic review of anti-rheumatic medicinal plants: An overview of the effectiveness of articular tissues and joint pain associated with rheumatoid arthritis". Journal of Pharmaceutical Sciences and Research 9.5 (2017): 547.

27. Ichsyani M., et al. "Antiviral effects of Curcuma longa L. against dengue virus in vitro and in vivo". In IOP Conference Series: Earth and Environmental Science 101.1 (2017): 012005. 
28. Sornpet B., et al. "Antiviral activity of five Asian medicinal plant crude extracts against highly pathogenic H5N1 avian influenza virus". Asian Pacific Journal of Tropical Medicine 10.9 (2017): 871-876.

29. Wahyuni T S., et al. "Antiviral activities of curcuma genus against hepatitis C virus". Natural Product Communications 13.12 (2018): 1934578X1801301204.

30. Wang Y., et al. "Choleretic activity of turmeric and its active ingredients". Journal of Food Science 81.7 (2016): H1800H1806.

31. Henrotin Y., et al. "Bio-optimized Curcuma longa extract is efficient on knee osteoarthritis pain: a double-blind multicenter randomized placebo-controlled three-arm study". Arthritis Research and Therapy 21.1 (2019): 179.

32. Abubakar A., et al. "Pharmacognostic, Physicochemical and Phytochemical Investigations on Aerial Parts of Argemone mexicana L". Research Journal of Pharmacognosy 7.3 (2020): $15-24$.

33. Fathuddin $\mathrm{M} M$ and Inabo H I. "In vitro antitrypanosomal potential of chloroform leaf extract of Punica granatum L. on Trypanosoma brucei brucei and Trypanosoma evansi". Microbiology Research 8.1 (2017).

34. World Health Organization. Handbook: good laboratory practice (GLP): quality practices for regulated non-clinical research and development. World Health Organization (2010).

35. Committee for the Purpose of Control and Supervision on Experiments on Animals. CPCSEA Guidelines for Laboratory Animal Facility (2010).

36. Ahmadu Bello University Ethics Committee on Animal Use and Care [ABUCAUC] (2010).

37. Hosea ZY., et al. "Phytochemical Properties and Antimicrobial Activities of Aqueous Extract of Curcuma longa (Turmeric) rhizome extract". Asian Journal of Research in Crop Science (2018): 1-8.

38. Kasta G. "Antimicrobial Activity of Ethanol Extract of Rhizome Turmeric (Curcuma Longa L.) For Growth of Escherichia coli, Staphylococcus aureus and Candida albicans. Asian Journal of Pharmaceutical Research and Development 8.3 (2020): 5-8.

39. Win TT and Thandar S. "Identification of Isolated Curcumin from Rhizomes of Curcuma longa L. (Na-nwin) and Investigation of Antimicrobial Activity of the Various Crude Extracts". 3rd Myanmar Korea Conference Research Journal Dagon University 3.5 (2020).
40. Le TB., et al. "Evaluation of the anti-trypanosomal activity of vietnamese essential oils, with emphasis on Curcuma longa $\mathrm{L}$. and its components". Molecules 24.6 (2019): 1158.

41. Haddad M., et al. "Curcuma as a parasiticidal agent: a review”. Planta medica 77.6 (2011): 672-678.

42. Jonah A O and Enoh E. "In vitro Anti-trypanosomal activity of curcumin isolated from Curcuma longa (Turmeric) rhizomes". Journal of Entomology and Zoology Studies 8.2 (2020): 729731.

43. Bhat S V., et al. "Biological Activities of Turmeric (Curcuma longa Linn.)-an overview”. BMR Microbiology 1.1 (2015): 1-5.

44. Mody D., et al. "Curcumin: A Natural Derivative with Antibacterial Activity Against Clostridium difficile". Journal of Global Antimicrobial Resistance 21 (2020): 154-161.

\section{Assets from publication with us}

- Prompt Acknowledgement after receiving the article

- Thorough Double blinded peer review

- Rapid Publication

- Issue of Publication Certificate

- High visibility of your Published work

Website: https://www.actascientific.com/

Submit Article: https://www.actascientific.com/submission.php Email us: editor@actascientific.com

Contact us: +919182824667 